Article

\title{
Effects of Ecological Water Conveyance on the Hydrochemistry of a Terminal Lake in an Inland River: A Case Study of Qingtu Lake in the Shiyang River Basin
}

\author{
Yu Zhang ${ }^{1}{ }^{\mathbb{D}}$, Guofeng Zhu ${ }^{1,2, *}$, Huiying Ma ${ }^{1}{ }^{\mathbb{D}}$, Jianxia Yang ${ }^{1}$, Hanxiong Pan ${ }^{1}$, Huiwen Guo ${ }^{1}$, \\ Qiaozhuo Wan ${ }^{1}$ and Leilei Yong ${ }^{1}$ \\ 1 College of Geography and Environment Science, Northwest Normal University, Lanzhou 730070, China \\ 2 State Key Laboratory of Cryospheric Science, Northwest Institute of Eco-Environmental Resources, Chinese \\ Academy of Sciences, Lanzhou 730000, China \\ * Correspondence: gfzhu@lzb.ac.cn or guofengzhu@me.com; Tel.: +86-139-0931-0867; Fax: +86-0931-797-1565
}

Received: 10 July 2019; Accepted: 9 August 2019; Published: 13 August 2019

\begin{abstract}
Along with the growth of the population and economic and social development, water consumption in the upper-middle reaches of inland rivers is increasing, which has resulted in long-term cutout in the lower reaches of the river, shrinkage and drying up of the wetlands around the terminal lakes, and has caused a series of ecological problems at the same time. In order to protect the fragile ecological environment, comprehensive harnessing projects have been carried out in many inland river basins in China, in which adopting ecological water conveyance to rehabilitate degraded terminal lakes and wetlands is an important means. From June 2014 to October 2017, the water in the upper-middle reaches of the Shiyang River Basin and the lake water of the terminal lake after ecological water conveyance was sampled. The effects of ecological water conveyance on the characteristics of surface water and groundwater were analyzed using, for example, the Piper triangle diagram, Gibbs boomerang envelope model, and mixing diagram. After ecological water conveyance, the ion concentration of water in Qingtu Lake was higher overall, and ion concentration of water in the unstable catchment was higher than that of the stable catchment. The time variation was characterized as high in the summer half year and low in the winter half year. The water of Qingtu Lake is of high and large salinity, and its hydrochemical type is $\mathrm{Na}-\mathrm{SO}_{4}(\mathrm{Cl})$, which is obviously different from the water in the middle-upper reaches of the Shiyang River Basin. The effects of silicate weathering and evaporation crystallization are the main factors leading to the high ion concentration in the water of Qingtu Lake. Ecological water conveyance and the strong evaporation of arid areas have intensified the salinization of water and soils in Qingtu Lake. Meanwhile, implementing the ecological water conveyance policy in the terminal lake has also led to shortage of water resources for agricultural irrigation in the middle reaches of the Shiyang River Basin. The serial negative ecological effects of the ecological water conveyance should be emphasized.
\end{abstract}

Keywords: arid area; terminal lake; ecological water conveyance; salinization of water

\section{Introduction}

As a relatively closed water circulation system, the characteristics and evolution mechanism of terminal lakes are similar and different from those of rivers [1,2]. The evolution of lakes is influenced by atmospheric subsidence, evaporation-crystallization, surface lithology, and biological activities, and it is sensitive to human activities [3,4]. Large-scale manual intervention will lead to drastic changes in natural processes, such as the hydrologic cycle, land use change, and the hydrochemical 
characteristics of surface and groundwater around lakes [5-7]. The ecological water conveyance project is an important way of water resource regulation, which is widely used in arid and semiarid areas, such as Central Asia, Western Australia, and Northwest China. It is of great significance to the restoration and reconstruction of vegetation and ecological environment in the arid region [8-10]. The ecowater conveyance project can effectively curb a series of ecological and environmental problems, such as desertification, biodiversity loss, and imbalance between supply and demand and uneven spatial distribution of water resources in the lower reaches of the basin [11-13].

Aiming at the ecological environment problems of the lower reaches of the basin and the terminal lake, corresponding water resource dispatching policies were implemented in different areas. A large dam was built in the Aral Sea in 2003 to alleviate the salinization caused by the shrinking area of the Aral Sea [14]. The function of the dam is to adjust the area of the North Aral Sea by controlling the flow rate, but it accelerates the shrinkage of the South Aral Sea [15]. Since 2000, in order to improve the ecological environment of the lower reaches of the Tarim River, the local river basin management has used the water resources of Lake Bosten to carry out ecological water conveyance in the lower reaches of the Tarim River. After water recharge, the burial depth of groundwater in the lower reaches of the Tarim River increased significantly, and the plant communities along the river recovered rapidly $[8,16]$. However, such practices have also resulted in soil and water salinization in the downstream areas [5]. The ecological water diversion policy of the Heihe River Basin has also realized the sustainable development of the ecological environment of its lower reaches (Juyan Lake basin), but it has also led to the continuous decline of the groundwater level in the middle reaches of the Heihe River Basin [17,18].

In order to meet the irrigation demand of the oasis area in the Shiyang River Basin, 12 large-scale water conservancy projects have been constructed in the upper-middle reaches since the 1950s. Among them, the Hongyashan Reservoir has the most obvious impact on the downstream area [19]. It dried up the downstream rivers, aggravated desertification, and caused irreversible ecological environmental damage to the terminal lake of the Shiyang River Basin [20]. In order to curb the continuous deterioration of the ecological environment in the lower reaches of the Shiyang River Basin, since 2010, the local river basin management departments have taken the successful experience ofthe ecological management of the Tarim River as a reference and carried out targeted control of the ecological environment in the lower reaches of the Shiyang River Basin, by means of artificial ecological water conveyance and transformation of the shelterbelt.

Ecological water conveyance is a common ecological measure in arid basins at present, but it was implemented for a short time in the Shiyang River Basin. Today, research on this policy mainly focuses on the effects of ecological water transportation on the regional vegetation coverage [21], hydrological changes on the vegetation pattern [22,23], the dynamic changes of groundwater level around lakes and the effects of ecological control [24], and the microclimate of lakes [25,26]. These research results provide a scientific and detailed theoretical basis for guiding human rational use of lake water resources and ecological environmental management. However, the existing results do not adequately describe the characteristics of water quality changes in the water body after ecological water conveyance. In the lower reaches of the arid inland river basin, the impact of strong evaporation and human activities on water quality cannot be ignored. The purpose of this work is to study the temporal and spatial variations of the hydrochemical characteristics of the terminal lake in the inland river basin, the factors controlling the hydrochemistry of the lake, the differences between the terminal lake and the upper-middle reaches of the river after ecological water conveyance, and to regard ecological water conveyance from the perspective of the impact of ecological water conveyance on the water environment of the terminal lake in the arid inland river basin. This paper provides a more scientific reference for avoiding the negative effect of ecological water conveyance and realizing the sustainable development of the basin as far as possible. 


\section{Study Area}

Qingtu Lake, the terminal lake of Shiyang River Basin, is located at the northern end of Minqin Oasis, at the junction of the eastern edge of the Badain Jaran Desert and the western edge of the Tengger Desert. This area is also a staggered area between the East Asian monsoon and nonmonsoon regions. Its unique geographical location makes it a sensitive area for climate change. The average altitude of the lake is about $1300 \mathrm{~m}$, and it is located in the arid and extremely arid regions of the middle temperate zone. The local topography is dominated by sand dune plains. The biodiversity in Qingtu Lake is single, and the vegetation types are mainly temperate semishrub desert vegetation and dwarf semishrub desert vegetation. The climate type around Qingtu Lake is a temperate continental arid climate. In addition, the annual total radiation is $6000 \mathrm{MJ} / \mathrm{m}^{2}$, the annual average temperature is $8{ }^{\circ} \mathrm{C}$, the daily temperature range is more than $15^{\circ} \mathrm{C}$, the local precipitation is less, the annual evaporation is extremely strong, the annual precipitation is less than $110 \mathrm{~mm}$, and the annual evaporation is above $2500 \mathrm{~mm}$ [27]. The water budget of Qingtu Lake is seriously unbalanced. The surface sediments of Qingtu Lake are mainly fluvial and lacustrine sediments, and the lake region is surrounded by a large area of desert, while the main sediments are sandy conglomerate and sandy clay. The water recharge of Qingtu Lake is mainly ecological water conveyance discharged from reservoirs in the middle reaches of the basin, and the recharge capacity of local precipitation and groundwater in the lake area is limited. The groundwater in the lake area is mainly recharged by surface runoff infiltration caused by precipitation in the Qilian Mountains and eventually slowly migrates to the desert. The relationship between surface water and groundwater recharge is that surface water recharges the groundwater (Figure 1).

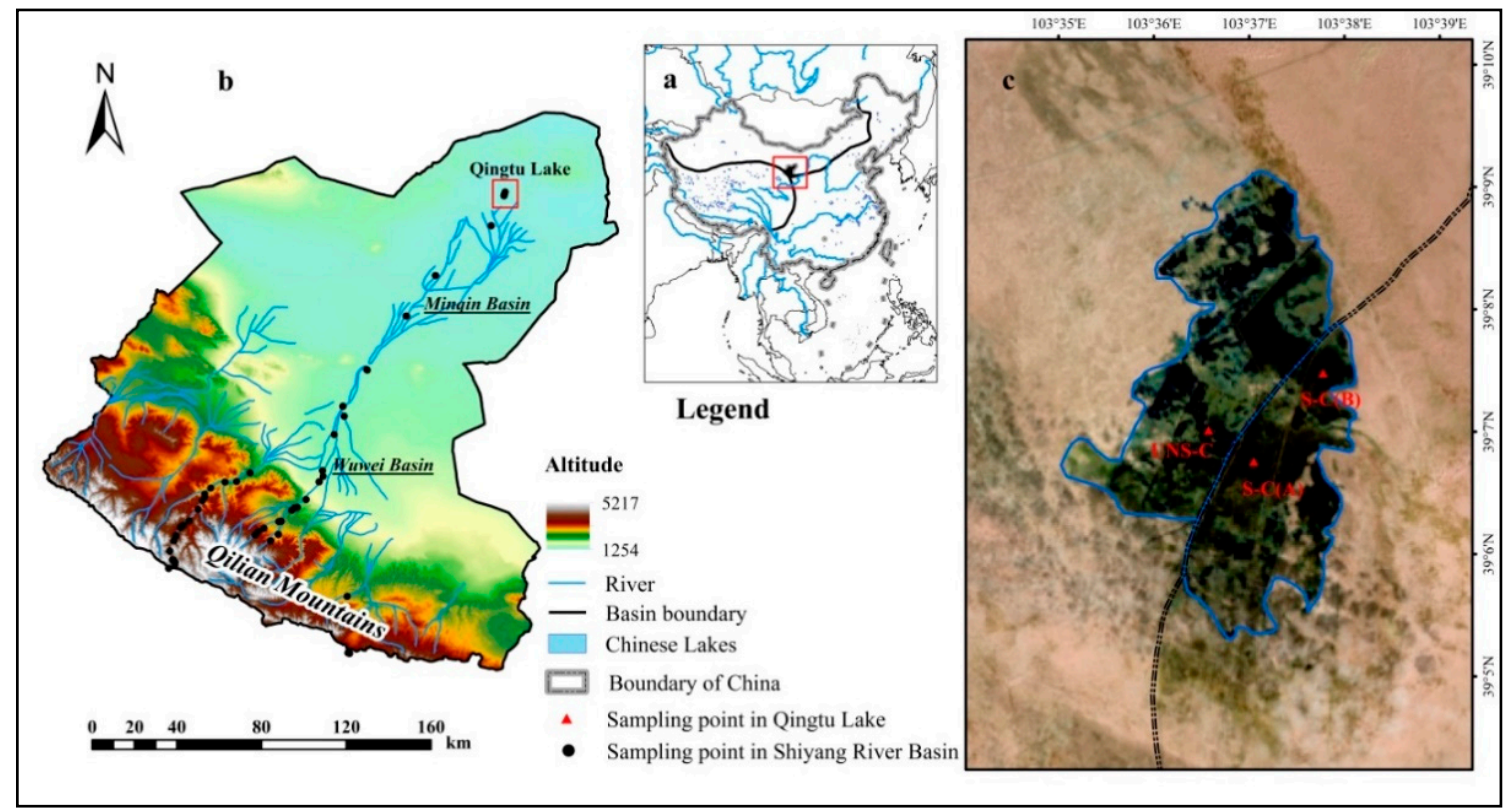

Figure 1. A diagrammatic sketch of study area: (a) Location of the Shiyang River Basin in East Asia; (b) location of Qingtu Lake in the Shiyang River Basin; (c) location and boundary of the catchment of Qingtu Lake based on remote sensing images (https://glovis.usgs.gov), in which the dark area is water and the rest is desert.

In the 1950s, the construction of the Hongyashan Reservoir in the middle reaches of the Shiyang River caused the terminal lake of the Shiyang River to dry up quickly, and desertification of the Minqin Oasis in the lower reaches intensified [20]. Since the 1960s, there have been a series of ecological problems in the lower reaches of the Shiyang River, such as the decline of groundwater level, vegetation degradation, soil salinization, and other issues [24,28]. Since 2010, the local government has carried out targeted treatment on the ecological environment problems of the lower Shiyang River by means 
of artificial ecological water conveyance and so on, and the area of the desert has been controlled effectively. In recent years, with the increase of water delivery, the water area of the lake has expanded year by year. By 2016, the area of the catchment had reached more than $25 \mathrm{~km}^{2}$, and the depth of the groundwater table had lifted by $0.79 \mathrm{~m}$ compared to that before the water delivery (Table 1 ).

Table 1. Changes of water inflow and water quantity in Qingtu Lake from 2010 to 2016.

\begin{tabular}{ccccc}
\hline $\begin{array}{c}\text { Time } \\
\text { (year) }\end{array}$ & $\begin{array}{c}\text { Total Water Inflow } \\
\text { into the Lake } \\
\left(\mathbf{1 0}^{\mathbf{4}} \mathbf{~ m}^{\mathbf{3}}\right)\end{array}$ & $\begin{array}{c}\text { Water Surface } \\
\text { Area of Catchment } \\
\mathbf{( 1 0}^{\mathbf{6}} \mathbf{~}^{\mathbf{2}}\end{array}$ & $\begin{array}{c}\text { Buried Depth of } \\
\text { Groundwater } \\
\mathbf{( m )}\end{array}$ & $\begin{array}{c}\text { Annual Change of } \\
\text { Groundwater Depth } \\
\mathbf{( m )}\end{array}$ \\
\hline 2008 & - & - & 3.91 & - \\
2009 & - & - & 3.84 & -0.07 \\
2010 & 1290 & 3.00 & 3.78 & -0.06 \\
2011 & 2160 & 10.00 & 3.60 & -0.18 \\
2012 & 3000 & 15.00 & 3.54 & -0.06 \\
2013 & 2000 & 15.00 & 3.46 & -0.08 \\
2014 & 3300 & 22.00 & 3.20 & -0.26 \\
2015 & 2833 & 22.36 & 3.14 & -0.06 \\
2016 & 3358 & 25.20 & 2.99 & -0.15 \\
\hline
\end{tabular}

Note: Data are from the statistical yearbook of Wuwei, and the Tatol water inflow into the lake: Total water from upstream to Qingtu Lake; water surface area of catchment: Area of water surface formed in Qingtu Lake.

\section{Data and Methods}

\subsection{Sampling and Chemical Analysis}

From June 2014 to October 2017, the water body and surrounding environment of Qingtu Lake were monitored and sampled after three years of ecological water conveyance. The sampling interval was 30 days, setting up 3 sampling points in Qingtu Lake and collecting 108 samples. According to the actual situation, the sampling points were called stable catchment A (S-C(A)), stable catchment B (S-C(B)), and unstable catchment (UNS-C), respectively, of which stable catchments A and B are located in perennial catchments and the unstable catchment is located in seasonal catchments. At the same time, we built 49 sampling points in the upper and middle reaches of the Shiyang River Basin to sample the river water, and a total of 366 samples were collected. During the sampling process, the polyethylene plastic vial previously rinsed with demonized water was rinsed three times with water from the sample point, and immediately sealed and cryopreserved. The samples were transported to the State Key Laboratory of Cryospheric Sciences, Northwest Institute of Ecology and Environmental Resources, Chinese Academy of Sciences, and preserved at $-15{ }^{\circ} \mathrm{C}$ in cold storage. Before the experiment, the samples were naturally thawed at a room temperature of $23^{\circ} \mathrm{C}$ and filtered with a filter membrane (JINTENG, Tianjin, China) before the measurement, whose thickness is $0.45 \mu \mathrm{m}$. The main cations concentrations $\left(\mathrm{Ca}^{2+}, \mathrm{Mg}^{2+}, \mathrm{Na}^{+}\right.$, and $\left.\mathrm{K}^{+}\right)$were tested through Dionex-600 ion chromatography (Dionex, Sunnyvale, $\mathrm{CA}, \mathrm{USA}$ ), and the main anions concentrations $\left(\mathrm{Cl}^{-}, \mathrm{NO}_{3}{ }^{-}\right.$and $\mathrm{SO}_{4}{ }^{2-}$ ) were tested through Dionex-3000 ion chromatography (Dionex, Sunnyvale, CA, USA). The accuracy of the instrument can reach $\mathrm{ng} \mathrm{g}^{-1}$ level; the error is less than $5 \%$. At the same time, water quality indexes such as total electrical solid solubility (TDS), conductivity (EC), and salinity (SAL) were measured and calculated with a DDS-307 conductivity meter (Leici, Shanghai, China). At the same time, it should be noted that the remote sensing images used in the study were from USGS (https://glovis.usgs.gov/).

\subsection{Analytical Methods}

After the test, the acid ion content in all samples was estimated via an ion charge balance equation. The calculation formula is as follows:

$$
\sum_{\text {cation }}=\sum_{\text {anion' }}
$$




$$
\mathrm{C}_{\mathrm{HCO}_{3}^{-}}=\mathrm{C}_{\text {cation }}-\mathrm{C}_{\left(\left[\mathrm{SO}_{4}^{2-}\right]+\left[\mathrm{Cl}^{-}\right]+\left[\mathrm{NO}_{3}^{-}\right]\right)} .
$$

In Equations (1) and (2), the $\mathrm{C}$ is the concentration of ions. Based on the above calculation formulas, the ion concentration of $\mathrm{HCO}_{3}{ }^{-}$was calculated. Combined with the geostatistical methods, the sample characteristics of main ions and the spatial and temporal variability of ion concentration were analyzed by Origin 9 software (OriginLab, Northampton, MA, USA). The ion composition and hydrochemical types of the upper-middle reaches of the Shiyang River Basin and Qingtu Lake were discussed by projecting the measured sample data into the Piper triangle diagram. At the same time, the influence of surface sediment and rock weathering on hydrochemistry was preliminarily judged by the Gibbs boomerang envelope model and mixing diagram.

\section{Results and Analysis}

\subsection{Hydrochemistry Characteristics after Ecological Water Conveyance}

The water chemical parameters of 118 samples from three sampling points in Qingtu Lake after artificial water conveyance were analyzed. The results showed that the water in Qingtu Lake was weak alkaline, with an average $\mathrm{pH}$ value of 8.18 and a range of 7.19 to 9.14; the average SAL (salinity) was $10.84 \mathrm{ppt}$, and the variation range was between 0.2 and $60 \mathrm{ppt}$; the average TDS of the water samples in the range of instrument detection was $19,749.14 \mathrm{mg} \mathrm{L}^{-1}$, and the variation range was 614 to $97,400 \mathrm{mg} \mathrm{L}^{-1}$, and the TDS of some samples exceeded the instrument monitoring limit of $20,000 \mathrm{mg} \mathrm{L}^{-1}$. The average TDS of Qingtu Lake was above $50,000 \mathrm{mg} \mathrm{L}^{-1}$. The concentration of $\mathrm{CO}_{3}^{2-}$ in weak alkalinity water accounted for less than $5 \%$ of the total of weak acid ions, so it is not discussed in the paper. The concentration of $\mathrm{HCO}_{3}{ }^{-}$of water in the paper was estimated by the equation of conservation of anion and cation charge [29].

Four main cations $\left(\mathrm{Ca}^{2+}, \mathrm{Mg}^{2+}, \mathrm{Na}^{+}\right.$, and $\left.\mathrm{K}^{+}\right)$and three main anions $\left(\mathrm{Cl}^{-}, \mathrm{HCO}_{3}{ }^{-}\right.$, and $\left.\mathrm{SO}_{4}{ }^{2-}\right)$ in water samples of Qingtu Lake were analyzed. It was found that the order of the average concentration of the main cations in Qingtu Lake was $\mathrm{Na}^{+}>\mathrm{Mg}^{2+}>\mathrm{Ca}^{2+}>\mathrm{K}^{+}$. The average concentration of $\mathrm{Na}^{+}$was $2898.37 \mathrm{mg} \mathrm{L}^{-1}$, accounting for $65.31 \%$ of the total amount of cations, followed by $\mathrm{Mg}^{2+}$, whose average concentration was $834.16 \mathrm{mg} \mathrm{L}^{-1}$; the average concentration of $\mathrm{Ca}^{2+}$ was $561.43 \mathrm{mg} \mathrm{L}^{-1}$; the average concentration of $\mathrm{K}^{+}$was the lowest, whose average concentration was $143.99 \mathrm{mg} \mathrm{L}^{-1}$, and the content of $\mathrm{Na}^{+}$with the highest concentration was 15 times that of the lowest $\mathrm{K}^{+}$. As for the total number of cations, $\mathrm{Na}^{+}$and $\mathrm{K}^{+}$contributed to $68.55 \%$, while $\mathrm{Mg}^{2+}$ and $\mathrm{Ca}^{2+}$ accounted for $18.79 \%$ and $12.65 \%$ of the total amount of cations, respectively. After analyzing the average concentration of major anions, we found that the highest concentration of anion in Qingtu Lake was $\mathrm{SO}_{4}{ }^{2-}$, and the average concentration was $1882.34 \mathrm{mg} \mathrm{L}^{-1}$, followed by $\mathrm{Cl}^{-}$, the average concentration was $1650.72 \mathrm{mg} \mathrm{L}^{-1}$; $\mathrm{HCO}_{3}{ }^{-}$was the lowest, and the average concentration was $779.65 \mathrm{mg} \mathrm{L}^{-1}$. The ratio of the above ions in the total anions was $43.64 \%, 37.27 \%$, and $18.08 \%$, respectively (Table 2).

According to the Mischka Lev classification method, the hydrochemical type of Qingtu Lake is $\mathrm{Na}-\mathrm{SO}_{4}(\mathrm{Cl})$. This is significantly different from the whole hydrochemical type $\left(\mathrm{Ca}-\mathrm{HCO}_{3}\left(\mathrm{SO}_{4}\right)\right)$ of the Shiyang River Basin (Figure 2) [19,30]. According to TDS classification, the characteristics of Qingtu Lake have changed from freshwater $\left(\mathrm{TDS} \approx 373.4 \mathrm{mg} \mathrm{L}^{-1}\right)$ to extremely salty water $(10,000<$ TDS $<35,000 \mathrm{mg} \mathrm{L}^{-1}$ ), with some of the samples even showing the characteristics of salt brine (TDS > $35,000 \mathrm{mg} \mathrm{L}^{-1}$ ). Compared to the upper-middle reaches of the Shiyang River Basin, the characteristic of salinization in Qingtu Lake is obvious [31,32]. The main causes for this phenomenon are the strong evaporation from the water surface and the depositional environment at the bottom of the lake after ecological water conveyance, which makes water evaporate and the salinity sink in the lake. The amount of evaporation in the lake outclasses the supply of freshwater from the upper reaches, so the content of $\mathrm{Cl}^{-}$and $\mathrm{Na}^{+}$in Qingtu Lake is higher, and the water shows a tendency of salinization. 
Table 2. Descriptive statistics of hydrochemistry of all available water samples (Units: $\mathrm{mg} \mathrm{L}^{-1}$, except $\mathrm{pH})$.

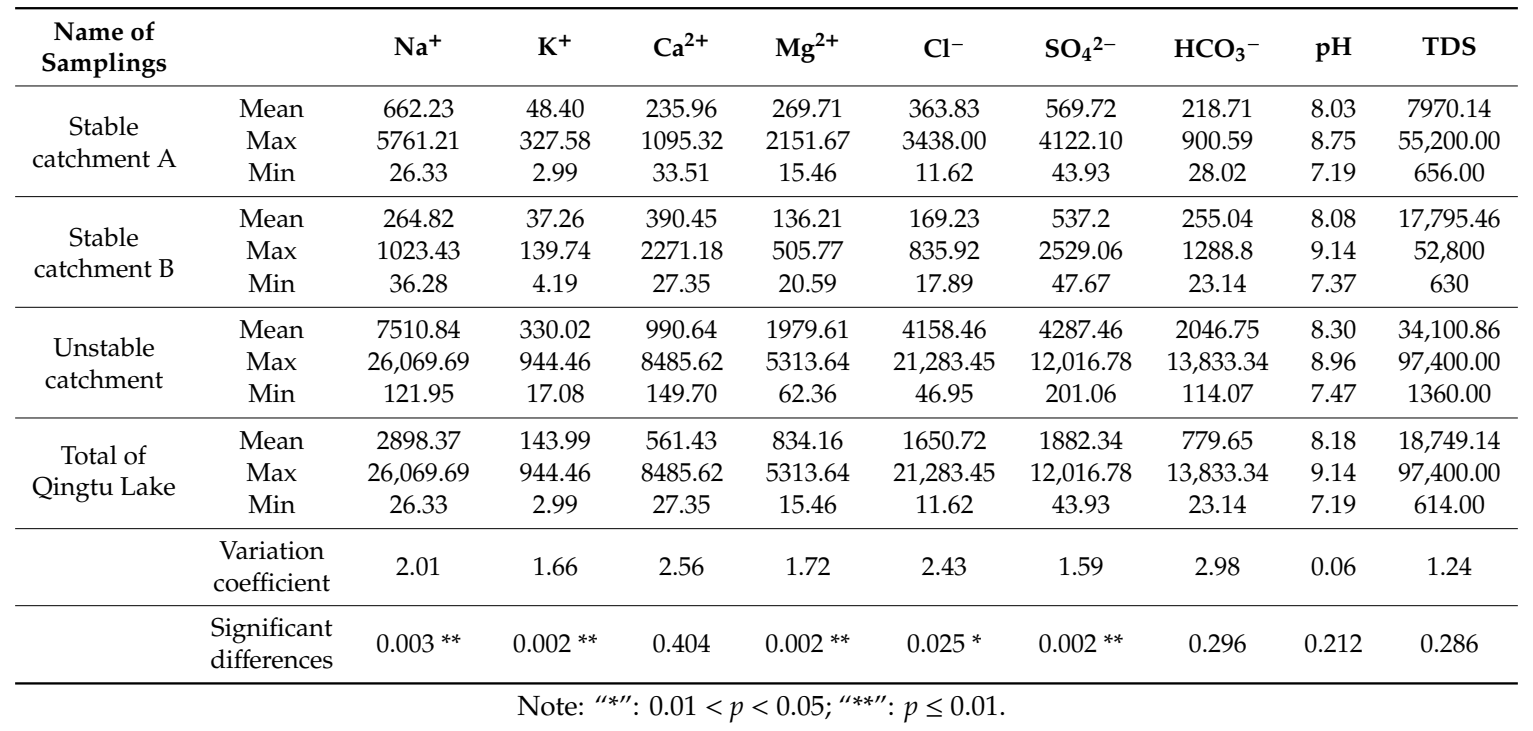
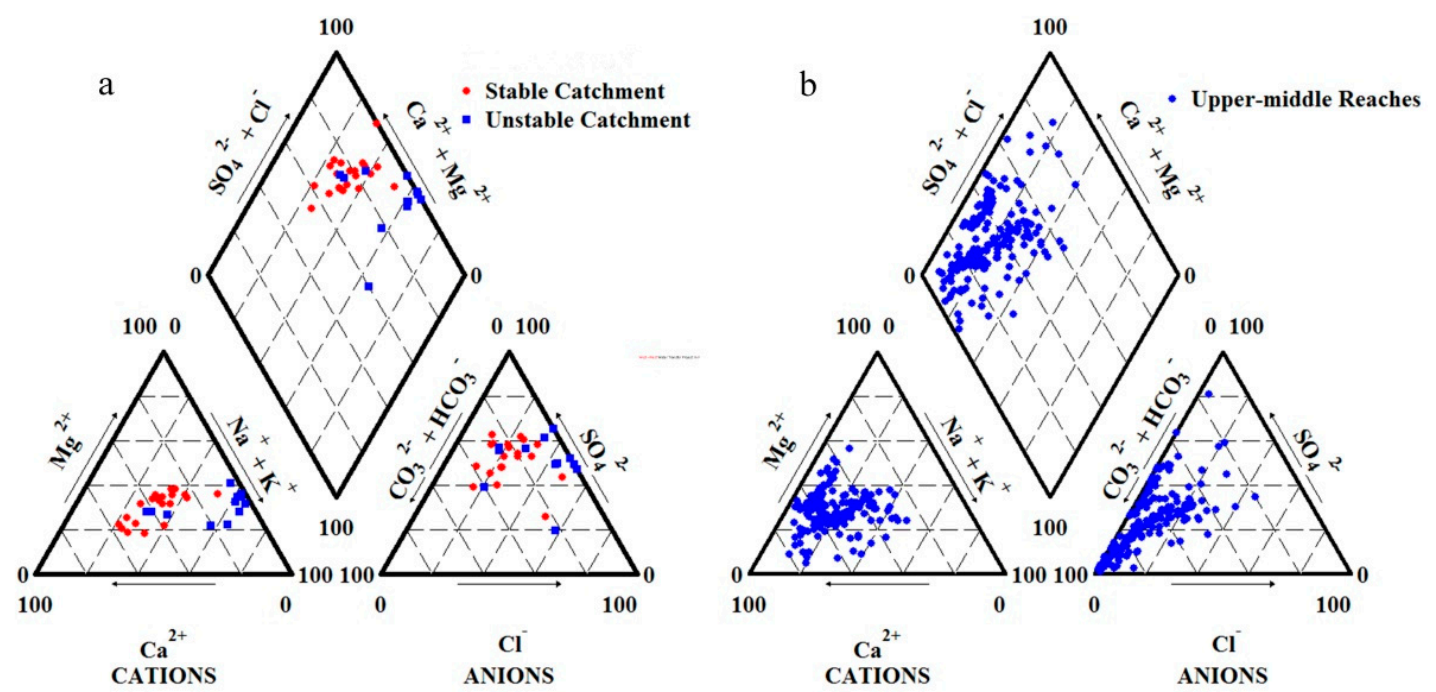

Figure 2. Piper diagram of main ions composition of Qingtu Lake (a) and upper-middle reaches of the Shiyang River Basin (b).

\subsection{Characteristics of Lake Water Ions Composition of Lake after Ecological Water Conveyance}

The chemical characteristics of water are the result of the combination of water itself and diagenetic minerals. The Piper three-line diagram can provide a basic and intuitive graphical interpretation of the water-rock reaction, revealing the evolution process of water and the movement rule of salt in water. Meanwhile, it is a necessary means to determine the chemical composition of water and the hydrochemical type of water [33]. We drew the Piper diagram using the percentage of $\mathrm{mEq}$ (milligram equivalent) of the main ions in the water (Figure 2). The results show that (1) the sample data were highly dispersed within the model, indicating that the salinity of the water in Qingtu Lake is higher; (2) most of the points in the cations triangulation were concentrated in the middle part of the triangle, with some of the data located in the lower right corner, indicating that the advantage of $\mathrm{Na}^{+}$and $\mathrm{K}^{+}$in Qingtu Lake is obvious. However, there were differences in the characteristics of water at different locations. The concentrations of alkali metal ions and alkali earth metal ions in the water from the stable catchment were balanced, but the proportion of $\mathrm{Na}^{+}$and $\mathrm{K}^{+}$was higher than that in the unstable catchment; (3) in the anionic triangulation, except for the sporadic sample points, the rest of the samples 
were all located in the middle and upper area, which proves that the proportion of sulfate in water is larger; and (4) the positional relationship of the rhomboid region can simply explain the hydrochemical type of Qingtu Lake. According to the location information of samples in the diamond, we can infer that the hydrochemical type of Qingtu Lake is mixed water mainly composed of alkali metals and strong acids, which further indicates that the type of Qingtu Lake is $\mathrm{Na}-\mathrm{SO}_{4}(\mathrm{Cl})$, and the water in different regions has different characteristics. The cation group is inclined to the $\mathrm{Na}^{+}+\mathrm{K}^{+}$end element and the anionic component is inclined to the $\mathrm{SO}_{4}{ }^{2-}+\mathrm{Cl}^{-}$end element, indicating that the influences of evaporation and crystallization on the water in Qingtu Lake are obvious. Some data fell in the lower left quarter of the triangular chart, indicating that the lake is also affected by the surface carbonate rocks slightly.

\subsection{The Temporal Changes in Ion Concentration of Qingtu Lake}

The monthly variation characteristics of sampling point ion concentration and average ion concentration of Qingtu Lake in different locations of Qingtu Lake from June 2015 to May 2016 were analyzed. The results showed that the variation of water ion concentration in the summer half year is higher, and lower in the winter half year, and the average concentration of ions in Qingtu Lake has two obvious peak values, and the anion and cation exhibit the same concentration change rule (Figure 3). However, there are significant differences in the monthly variation of ion concentration in different regions: The peak ion concentration in stable catchment A appeared in July, and the amplitude was large and the oscillation period was long, while the ion concentration dropped significantly in the next month, and the ion concentration dropped sharply in other months. Further, the trend of change tended to be horizontal; there were two distinct peaks in the ion concentration of the unstable catchment in Qingtu Lake. The first peak appeared in August, the second peak appeared in April the next year, and the high ion concentration lasted for three months. There were three distinct periods of variation in the ion concentration of stable catchment B. The peak ion concentration appeared in June, August, and December, respectively. Among them, stable catchment B had the highest ion concentration in August, and the variation range was the smallest in all regions.

The reasons for the overall variation of ion concentration in Qingtu Lake are as follows. Firstly, the ion concentration in Qingtu Lake is affected by soluble particulates carried from upstream discharged water, and the water inflow from the upstream region is large in summer. During this period, water salinity is highly aggregated. Secondly, there is less precipitation around Qingtu Lake. The annual average precipitation was about $110 \mathrm{~mm}$ in the past years, but the evaporation is huge $(>2500 \mathrm{~mm})$. Evaporation in the summer half year accounts for $84 \%$ of the annual evaporation, and the recharge is much less than the evaporation around the lake. It also caused serious water imbalance in Qingtu Lake. The strong evaporation around the lake makes a large amount of water dissipate, resulting in evaporation of water and sedimentation of salinity. Therefore, the ion concentration of Qingtu Lake is high in the summer half year and the concentration is large, which is low in the winter half year.

Ion concentration in the edge of Qingtu Lake increased slightly in the winter half year (Figure 3c), which may be due to the fact that Qingtu Lake is located in the desert edge of the arid region of northwest China. The topsoil is saline-alkali soil, and soil salinization is serious here. In the winter half year, the surrounding ground of Qingtu Lake is dry, windy, with scarce precipitation, and the fraction of vegetation coverage is low. The above causes the salt in the soil to rise up through the capillary to the surface, and the return of salt will occur at this time. Therefore, the water dissolves and dilutes the soluble particles of the earth's surface, which will lead to the increase of ion concentration in the water.

The wave period of ion concentration from south to north is 1,2, and 3, respectively, and the peak value will change with the space variation, which is related to the law of salt migration in Qingtu Lake and the area change of the catchment area. The peak of ion concentration is delayed from north to south, because Qingtu Lake is a relatively closed-water circulation system compared to the river. According to the rule of "salinity movement with water", the movement of salinity is directly affected by the speed of water, and the kinematic velocity of water in the lake is slow; therefore, the movement 
of salinity in the water also slows down, resulting in the peak and low values of water ion concentration at different positions in Qingtu Lake appearing in time. The altitude of the north in Qingtu Lake is slightly higher than that of the south. Therefore, the catchment area of stable catchment A of Qingtu Lake is relatively stable, and the area of stable catchment B will change obviously with the increase or decrease of the amount of water entering the lake. At the same time, the change of impound-age will lead to frequent changes of ion concentration. Stable catchment A is close to the inlet of the lake, and the impoundage is relatively stable. Therefore, the amount of water entering the lake has little effect on the ion concentration of stable catchment A.
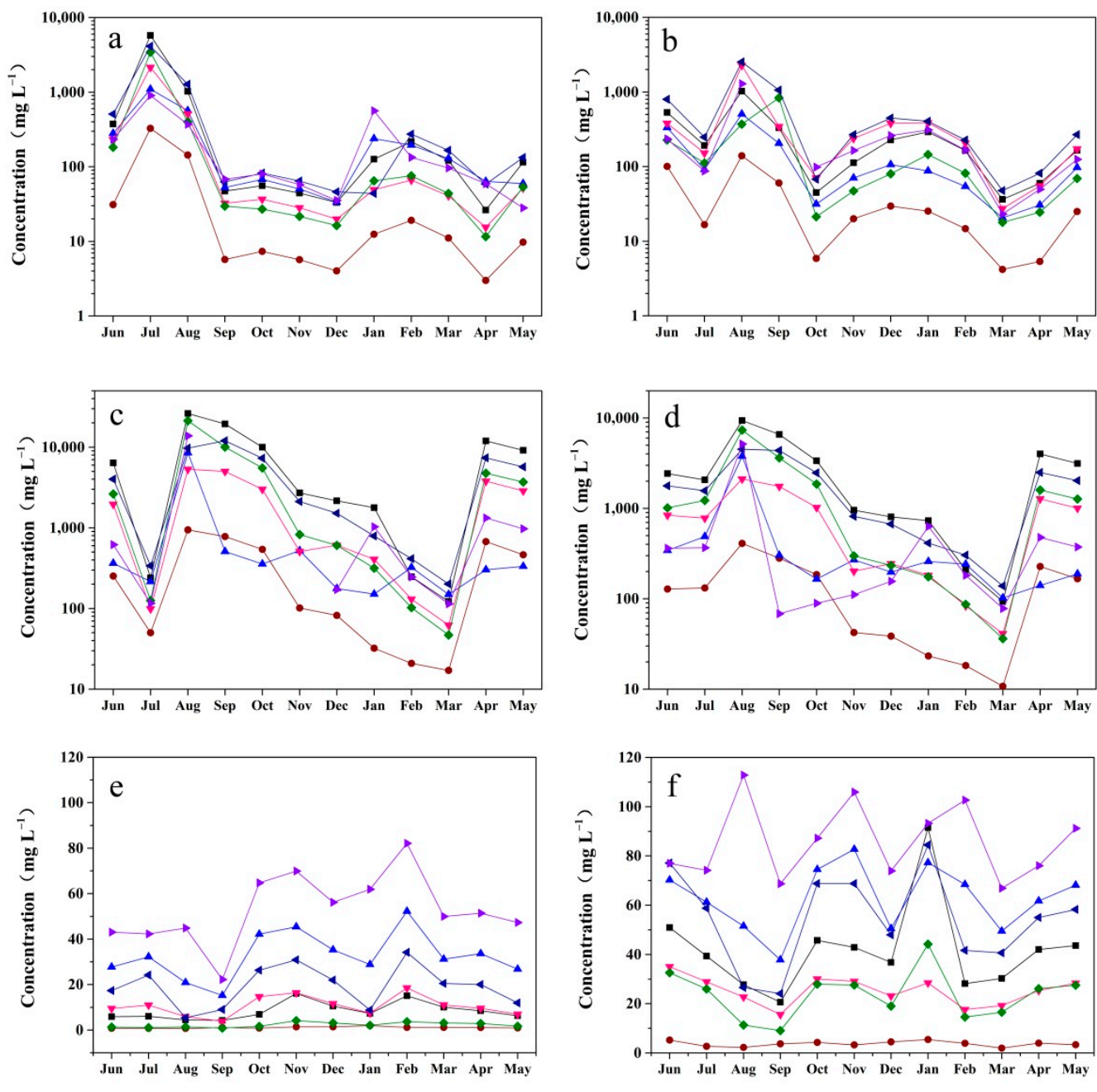

$$
\rightarrow \mathrm{Na}^{+} \longrightarrow \mathrm{K}^{+} \longrightarrow \mathrm{Ca}^{2+} \longrightarrow \mathrm{Mg}^{2+} \longrightarrow \mathrm{Cl}^{-} \leftarrow \mathrm{SO}_{4}^{2-} \rightarrow \mathrm{HCO}_{3}^{-}
$$

Figure 3. Monthly variation of ions composition in stable catchment A (a), stable catchment B (b), unstable catchment (c), total of Qingtu Lake (d), and upper (e) and middle (f) reaches of the Shiyang River Basin.

\subsection{Spatial Differences of Hydrochemistry Characteristics in Qingtu Lake}

The change of ion concentration in the surface water is influenced by the runoff process of the water, the petrochemical components in the flow region, and the surrounding natural condition. The effects of lithology and evaporation-crystallization are the dominant factors in the change of ion concentration of the lake in the arid area. The spatial variation rule of ions in Qingtu Lake was analyzed. It was found that the highest ion concentration in Qingtu Lake is located in the unstable catchment, followed by stable catchment $\mathrm{A}$, and ion concentration is the lowest in stable catchment B (Figure 4). This rule is caused by the ecological water conveyance projects of Qingtu Lake and a 
series of ecological effects. First of all, Qingtu Lake, as the terminal lake, is an aggregation place for water ions in the Shiyang River Basin. The unstable catchment is an unstable catchment area, where the reserved area is unstable after ecological water conveyance. Every time the lake area goes up and down, it is a process of salt accumulation in the water. Therefore, the concentration in the unstable catchment is much higher than that in other areas. Secondly, the climate and surficial deposit cannot be ignored. The strong surface evaporation after the lake bottom drying will cause salinity to deposit on the topsoil. After the next runoff, surface salinity will dissolve in water, and the accumulation of soluble particles in water makes the ion concentration of the unstable catchment much higher than that of stable catchment. In the past five years, the catchment area of Qingtu Lake has expanded rapidly, the area has multiplied, and the surface soluble particles also move with the water. The rule of spatial variation is the inevitable result of the movement rule of water and salt. According to the law of "salt movement with water", during the process of ecological water conveyance, there is a large amount of water influx in the lake in a short time, so that the own hydro-energy of the water can bring a large amount of salt to the unstable catchment of the lake. Therefore, the ion concentration of the unstable catchment will be significantly higher than that of the stable catchment when the salinity is accumulative at the unstable catchment. In terms of ion concentration in the stable catchment area, the concentration of stable catchment $A$ is higher than that of stable catchment $B$, which is caused by the altitude of Qingtu Lake. Stable catchment A has a lower altitude, and stable catchment B has a slightly higher altitude. Due to the gravitational potential energy, the salinity tends to move to the lower altitude area. Therefore, the ion concentration of stable catchment A is slightly higher than that of stable catchment B.

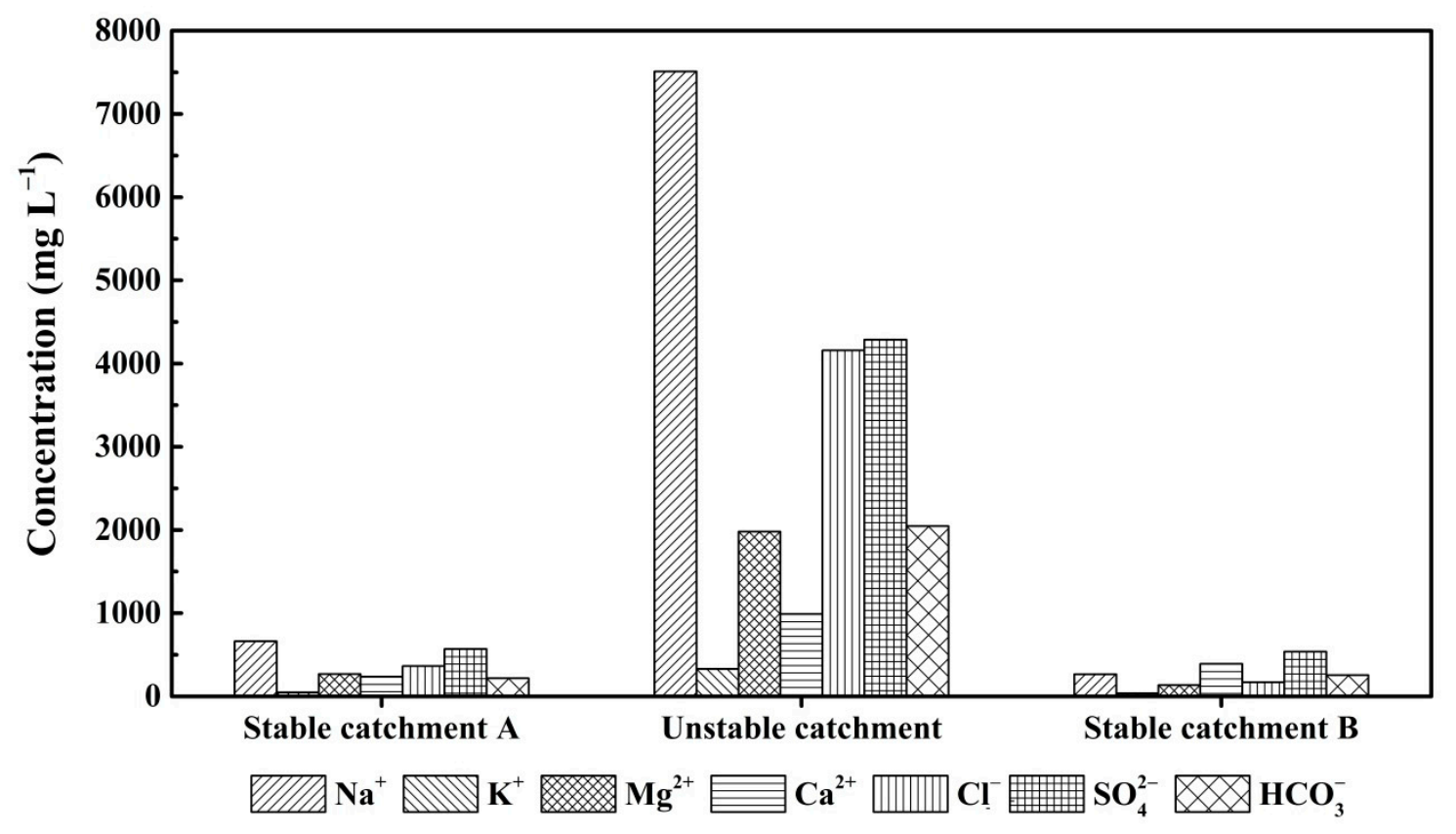

Figure 4. Spatial distribution of ion concentration in Qingtu Lake.

\section{Discussion}

\subsection{Controlling Factor of Hydrogeochemistry}

The chemical characteristics of natural water are usually influenced by three natural factors: rock weathering, atmospheric precipitation, and evaporation-crystallization. Generally, surface rock weathering products are the main sources of cations in water. The content of calcium and magnesium is greatly influenced by carbonate rocks. Sodium and potassium ions mainly come from silicate rocks weathering and strong evaporation-crystallization of the water surface. However, the source of anions in the water is complex and susceptible to human intervention [29,34]. The Gibbs diagram is one of 
the most commonly used methods to determine the relationship between natural control factors and ionic sources [3]. The model is mainly controlled by the ratio of TDS, $\mathrm{Na}^{+} /\left(\mathrm{Na}^{+}+\mathrm{Ca}^{2+}\right)$ or $\mathrm{Cl}^{-} /\left(\mathrm{Cl}^{-}\right.$ $+\mathrm{HCO}_{3}{ }^{-}$) to determine the major sources of ions in water. The location information of the samples can reflect the sources of the ions. By projecting the samples from the three points of Qingtu Lake to the Gibbs water chemistry boomerang envelope model (Figure 5), it can be seen that the distribution patterns of samples in Qingtu Lake were similar. Most of the data points fell in the end of evaporation crystallization and rock weathering of the Gibbs model. In other words, TDS was higher $\left(>300 \mathrm{mg} \mathrm{L}^{-1}\right)$, while the ratio of $\mathrm{Na}^{+} /\left(\mathrm{Na}^{+}+\mathrm{Ca}^{2+}\right)$ or $\mathrm{Cl}^{-} /\left(\mathrm{Cl}^{-}+\mathrm{HCO}_{3}{ }^{-}\right)$was dispersed. It was distributed in two intervals of $0-0.5$ and $0.5-1$, and no samples fell on the end of atmospheric precipitation. As we can find, the hydrochemical characteristics of Qingtu Lake are similar to those of lakes in the arid region of the Gibbs model from Figure 5. At the same time, the samples of stable catchment B and the unstable catchment are located in the upper-right region of the Gibbs model (TDS $\approx 100,000 \mathrm{mg} / \mathrm{L}$, and the ratio of $\left.\mathrm{Na}^{+} /\left(\mathrm{Na}^{+}+\mathrm{Ca}^{2+}\right) \approx 1\right)$. Gibbs studied the hydrochemical characteristics of surface water in the world and found that the samples of the Black Sea, Caspian Sea, and other saltwater lakes as well as the global ocean were mainly distributed in this region, which further illustrated that evaporative crystallization around Qingtu Lake is strong. The location of the samples in the Gibbs diagram shows that there is an obvious salinization trend in Qingtu Lake. The above results indicate that the hydrochemical characteristics of Qingtu Lake are mainly affected by rock weathering and surface evaporation-crystallization. The influence of atmospheric precipitation on the chemical characteristics of the water in Qingtu Lake can be ignored. The topsoil of Qingtu Lake is mainly composed of saline-alkali soil rich in chloride and chloride sulfate. This soil is rich in soluble salts. The perennial dry-lake causes the salt to emerge from the surface of the earth. After ecological water conveyance, the water will dissolve a large number of soluble salts in the surface water due to the leaching of sodium salts. The annual precipitation around Qingtu Lake is about $110 \mathrm{~mm}$, but annual evaporation is over $2500 \mathrm{~mm}$. The evaporation is 25 times the precipitation. The intense evaporation makes the water dissipate and the salts stay, aggravating the salinization of the water in Qingtu Lake. Moreover, the ratio of $\mathrm{Na}^{+} / \mathrm{Cl}^{-}$in Qingtu Lake is 1.75, higher than that of seawater (1.15), which is also caused by the above reasons.
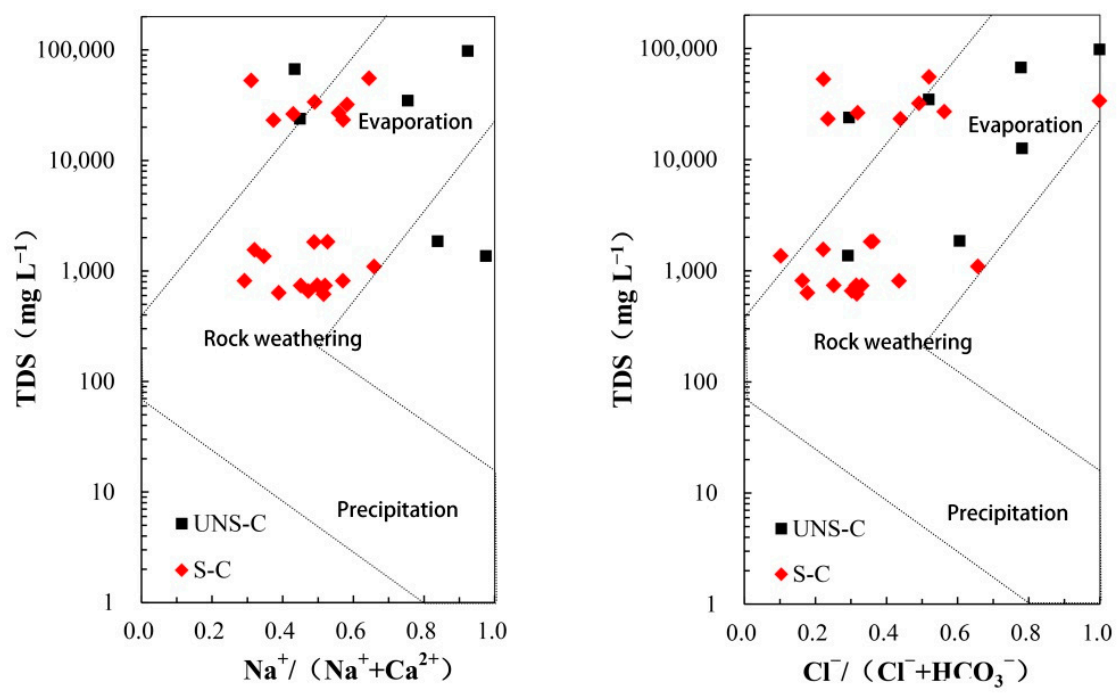

Figure 5. Gibbs diagram for the unstable catchment (UNS-C) and stable catchment (S-C) in Qingtu Lake.

\subsection{Chemical Weathering}

The contribution from the weathering and dissolution of carbonate, silicate, and evaporimeter salts to the hydrochemical character on surface waters can be quantitatively illustrated by the ions-mixing plot (Figure 6), prepared using a normalized ratio of sodium ion [35], which can further clarify the sources of water ions. We used the concentration of $\mathrm{Na}^{+}$to normalize the ratio of $\mathrm{Ca}^{2+}$ and $\mathrm{HCO}_{3}{ }^{-}$and 
$\mathrm{Ca}^{2+}$ and $\mathrm{Mg}^{2+}$ to determine the characteristics of rock weathering around Qingtu Lake. The results showed that most samples had lower ratios of $\mathrm{HCO}_{3}{ }^{-} / \mathrm{Ca}^{2+}(<3)$ and lower average ratios of $\mathrm{Mg}^{2+}$ and $\mathrm{Ca}^{2+}$ by $\mathrm{Na}^{+}(<1)$, indicating that silicates and evaporites have a high contribution to ion concentration, and carbonate evaporation contributes little to ion concentration (Figure 6). A large number of samples gathered in the transition area of evaporation rock and silicate, different water showed some differences, and water quality in different areas showed disparity. The water in the unstable catchment was more obviously influenced by the evaporite, followed by the silicate. The stable catchment was mainly affected by silicate, followed by the evaporite. Therefore, the above ionic relationships indicate that the hydrochemical characteristics of Qingtu Lake are caused by the weathering and dissolution of silicate and evaporite.
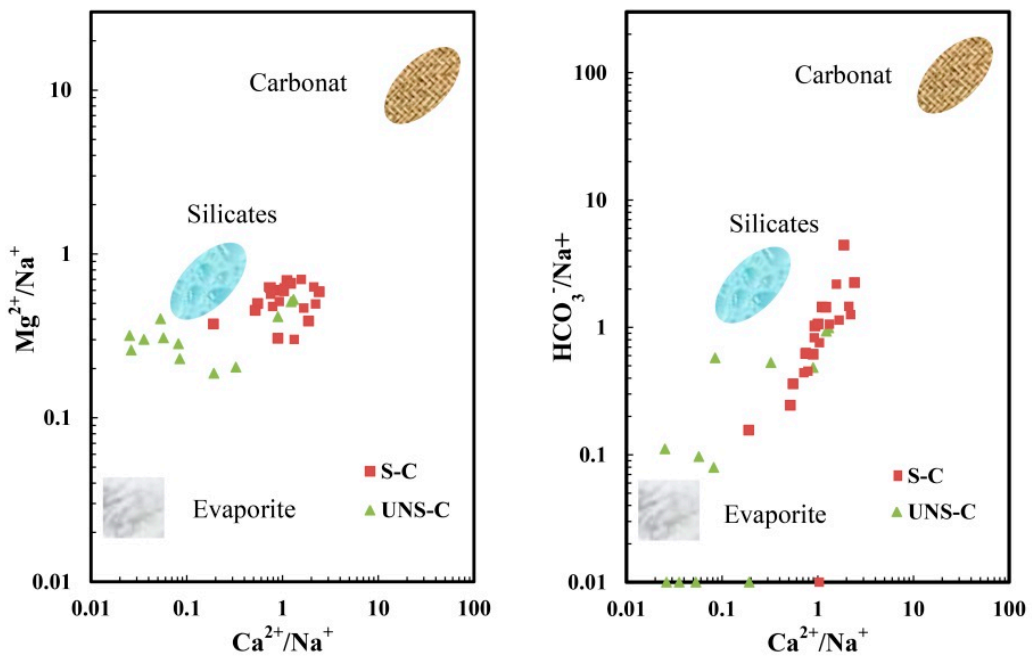

Figure 6. Mixing diagram of ion proportion for the stable catchment (S-C) and unstable catchment (UNS-C) in Qingtu Lake.

\subsection{Impact of Ecological Water Conveyance in Qingtu Lake}

\subsubsection{Soil and Water May Continue to Salinize in the Future}

After ecological water conveyance, the water hydrochemical type of Qingtu Lake is Na- $\mathrm{SO}_{4}$ $(\mathrm{Cl})$, and there are obvious differences from the upper-middle reaches of the Shiyang River Basin. The characteristics of the water samples in the Gibbs model are similar to those of the major saltwater lakes and oceans in the world [3]. Ecological water conveyance is changing the ecological environment of Qingtu Lake, while dissolving and adsorbing soluble salt from the surface rock and soil, which leads to the gradual increase of ion concentration in the water. Secondly, the strong evaporation of the surface caused the moisture in the aqueous solution to be vaporized, the salt was detained on the lake bed, and ion concentration in the lake would rise again. Therefore, the current ecowater transfer project may lead to sustained salinization of the water in the coccygeal end of the Shiyang River Basin.

The migration of salinity in soil and water is a direct result of the movement of water. The ecowater transfer project of Qingtu Lake not only changes the chemical characteristics of the surface water but also affects the hydrochemical characteristics of the groundwater. After ecological water conveyance, the rising trend of the water table at Qingtu Lake is obvious. However, when the groundwater level is elevated to the position near the ground, the large amount of accumulated salt in the shallow soil is dissolved by water, which leads to an increase in groundwater salinity and ion concentration $[5,36]$. The excessively high groundwater level will inevitably increase the evaporation and dissipation of surface water near the lake, and the final result is that the secondary salinization of the soil in Qingtu Lake is further aggravated. As for the ecological water conveyance effect and experience of the Tarim River, soil salinization is a possible result of the late stage of the ecological 
water conveyance project [8]. Since 2010, the water area of Qingtu Lake has been enlarged year by year with the increase of water transports. By 2016, the water area had reached more than $25 \mathrm{~km}^{2}$, and the buried depth of groundwater table had increased by $0.79 \mathrm{~m}$ compared to that before ecological water conveyance (Table 1). The groundwater hydrochemical characteristics of the same sampling point in the Minqin basin in 2010 and 2017 were compared, and the groundwater changes in the Minqin basin after ecological water conveyance were analyzed. The results showed that the concentrations of $\mathrm{Mg}^{2+}, \mathrm{Ca}^{2+}, \mathrm{K}^{+}, \mathrm{HCO}_{3}{ }^{-}$, and $\mathrm{SO}_{4}{ }^{2-}$ decreased, but the concentrations of $\mathrm{Cl}^{-}, \mathrm{Na}^{+}$, and TDS increased slightly compared with 2010 (Table 3). The hydrochemistry type of groundwater in the Minqin basin is similar to that in Qingtu Lake. Meanwhile, the water body is transforming into brackish water [37]. This phenomenon is similar to the hydrochemical characteristics of groundwater in the lower reaches of the Tarim River basin after ecological water conveyance. This result shows that, in the process of ecological water conveyance, surface water recharges groundwater. Under the influence of strong evaporation, the concentration and crystallization of groundwater is strengthened, resulting in sodium salting out and TDS increasing. The hydrochemical characteristics of groundwater have threatened the quality of agricultural irrigation and drinking water in the Minqin Oasis [38].

Table 3. Changes of groundwater hydrochemical characteristics in the Minqin Basin in 2010 and 2017 (Unit: $\mathrm{mg} \mathrm{L}^{-1}$ ).

\begin{tabular}{cccccccccc}
\hline Year & $\mathbf{H C O}_{3}{ }^{-}$ & $\mathbf{C l}^{-}$ & $\mathbf{S O}_{4}{ }^{2-}$ & $\mathbf{C a}^{2+}$ & $\mathbf{M g}^{2+}$ & $\mathbf{N a}^{+}$ & $\mathbf{K}^{+}$ & TDS & Origin \\
\hline 2010 & 267 & 93 & 307 & 97 & 40 & 109 & 7 & 921 & {$[37]$} \\
2017 & - & 98.95 & 159.58 & 54.45 & 36.67 & 179.24 & 0.89 & 1003 & This study \\
\hline
\end{tabular}

5.3.2. Comparison of Ion Concentration in Qingtu Lake and Upper-Middle Reaches of the Shiyang River Basin

The hydrochemical characteristics of Qingtu Lake and the upper-middle reaches of the Shiyang River Basin in the same period were compared. In terms of monthly variation of ion concentration and hydrochemical characteristics, there are great differences between the upper-middle reaches of the Shiyang River Basin and Qingtu Lake (Figures 2 and 3). The results showed that the concentration of all ions in Qingtu Lake was higher than that in the upper-middle reaches of the Shiyang River Basin, and there was a great difference between them. At the same time, the main anions and cations in Qingtu Lake have also changed. The main anions and cations in the upper-middle reaches of the Shiyang River Basin were $\mathrm{HCO}_{3}{ }^{-}$and $\mathrm{Ca}^{2+}$, respectively, while the main anions and cations in Qingtu Lake were $\mathrm{SO}_{4}{ }^{2-}, \mathrm{Cl}^{-}$, and $\mathrm{Na}^{+}$. Therefore, the hydrochemical types of Qingtu Lake and the upper-middle reaches of the basin are different. The hydrochemical types in the upper and middle reaches of the Shiyang River Basin are $\mathrm{Ca}-\mathrm{HCO}_{3}$ [30]. However, the results of this study show that the hydrochemical types of Qingtu Lake have evolved into a $\mathrm{Na}-\mathrm{SO}_{4}(\mathrm{Cl})$ type, which is also verified in Figure 2. TDS is an important index reflecting the characteristics of the water body. By comparing the average TDS values of Qingtu Lake and the upper-middle reaches of the Shiyang River, it was found that the spatial variation of TDS was very obvious. From the upper reaches to Qingtu Lake, TDS changed from 243 to 97,400 mg/L, and the water characteristics also changed from fresh water (TDS $<500 \mathrm{mg} / \mathrm{L}$ ) to saline water (TDS $>10,000 \mathrm{mg} / \mathrm{L}$ ) [32]. It is believed that the soluble particles in water will gradually enrich with the increase of distance, which accords with the evolution law of most rivers. However, the increase of ions in Qingtu Lake is greater than that in the upstream to the middle reaches. In fact, the distance between the two intervals is almost the same (Table 4). Rock weathering is the main factor affecting the overall water chemistry of the Shiyang River Basin, but there are also differences in different areas of the basin. The hydrochemical characteristics of the upper reaches of the basin are affected by precipitation, but the middle and lower reaches are also affected by evaporative crystallization. Due to the strong evaporation and crystallization around Qingtu Lake, the concentration of soluble particulate matter increased significantly after ecological 
water conveyance compared to that before entering the lake. Therefore, the salinization characteristics of the Qingtu Lake water body after ecological water conveyance are obvious.

Table 4. Descriptive statistics of ion concentration in Qingtu Lake and upper-middle reaches of the Shiyang River Basin (Unit: mg L ${ }^{-1}$ ).

\begin{tabular}{cccccccccc}
\hline Location & & $\mathbf{N a}^{+}$ & $\mathbf{K}^{+}$ & $\mathbf{M g}^{2+}$ & $\mathbf{C a}^{2+}$ & $\mathbf{C l}^{-}$ & $\mathbf{S O}_{4}{ }^{2-}$ & $\mathbf{H C O}_{3}{ }^{-}$ & $\mathbf{T D S}^{-}$ \\
\hline \multirow{2}{*}{ Upper } & Mean & 8.34 & 1.13 & 11.38 & 34.06 & 2.42 & 19.68 & 56.27 & 243.52 \\
reaches & Max & 47.88 & 5.68 & 36.82 & 134.18 & 22.52 & 128.03 & 146.86 & 575.00 \\
& Min & 1.21 & 0.09 & 0.50 & 3.64 & 0.04 & 0.38 & 2.29 & 43.00 \\
\hline \multirow{2}{*}{ Middle } & Mean & 22.94 & 2.36 & 13.57 & 33.06 & 9.91 & 20.36 & 64.12 & 338.01 \\
reaches & Max & 72.70 & 18.23 & 69.30 & 147.98 & 44.41 & 50.91 & 415.21 & 1210.00 \\
& Min & 1.63 & 0.54 & 0.69 & 8.39 & 0.15 & 0.43 & 12.69 & 48.00 \\
\hline \multirow{2}{*}{ Qingtu } & Mean & 2898.37 & 143.99 & 834.16 & 561.43 & 1650.72 & 1882.34 & 779.65 & $18,749.14$ \\
Lake & Max & $26,069.69$ & 944.46 & 5313.64 & 8485.62 & $21,283.45$ & $12,016.78$ & $13,833.34$ & $97,400.00$ \\
& Min & 26.33 & 2.99 & 15.46 & 27.35 & 11.62 & 43.93 & 23.14 & 614.00 \\
\hline
\end{tabular}

\subsection{Reflection on Ecological Water Conveyance Mode}

The implementation area of the Chinese ecowater conveyance project was mainly concentrated in inland river basins such as the Tarim River, Heihe River Basin, and Shiyang River Basin. Some studies have summarized the experience and results of ecological water conveyance in the Tarim river basin [5] and the Heihe basin [18] and found that the efficiency of single artificial river water conveyance is low. Therefore, opening up a multichannel water delivery model is also an effective way to improve water-use efficiency and restore the ecological environment. At the same time, we should control the comprehensive treatment of the whole basin by regulating the water consumption of the middle and upper reaches, changing the condition of vegetation combination, and planting salt-tolerant and drought-tolerant vegetation [8].

The inter-basin water conveyance project can effectively solve the worldwide problem of uneven distribution of water resources, meet the needs of human production and life, and ensure water resources and national security. Therefore, this means is popularized and applied globally. There are many successful cases, such as the Water Transfer Project in Pakistan, the North Water Transfer Project in the United States, and the South-to-North Water Transfer Project in China. This series of projects not only solved the problem of uneven distribution of water resources but also saved or delayed the regional ecological crisis temporarily. However, large-scale artificial intervention in a natural environment is bound to bring a series of negative effects, such as industrial and agricultural depression, climate variability, and ecological problems, which will gradually appear after years of accumulation [11].

In the early stage of implementing the ecowater transfer project in Qingtu Lake, the ecological environment in the region has obviously been improved. The diversity of vegetation communities increased, the lake effect formed by the lake surface obviously improved the local microclimate, and the humidity around the lake increased significantly. However, since the 1950s, the climate of the northwest inland areas of the west of Qingtu Lake and even Wushao Mountain has had an obvious trend of warming and drying to warming and wetting. Further, the amount of precipitation has increased by more than $10 \%$, the vegetation coverage has increased, and the days of sand-wind weather have decreased $[39,40]$. The desertification around Qingtu Lake stopped around 2008. Therefore, the ecological effect of ecological water conveyance has been difficult to quantify since 2010. Moreover, the lake region had been uninhabited before ecological water conveyance. The economic activities in the Shiyang River Basin are mainly concentrated in the Wuwei Oasis and Minqin Oasis in the upper-middle reaches, which also relies on the resources of the Shiyang River. With the further implementation of the ecowater transfer project, the pressure of water resources has increased in the middle reaches, salinization of the lake and soil have been aggravated in the lower reaches, and 
the vegetation coverage near the lake is declining. Some new social-economic and ecological issues have gradually become prominent. In order to improve the utilization efficiency of water resources, the watershed management department should firstly assess the scientificity and utilization efficiency of the existing water conveyance mode. Secondly, combined with the comprehensive environmental factors around Qingtu Lake and the water dissipation mechanism, we should arrange the ecological water conveyance mode and control water delivery and delivery time reasonably to prevent the risk of ecological water conveyance. While improving the surface ecological environment, we must also maintain the stability of water quality [41].

\section{Conclusions}

(1) The water in Qingtu Lake is weakly alkaline, with high salinity (SAL) and TDS, and the hydrochemical type is $\mathrm{Na}-\mathrm{SO}_{4}(\mathrm{Cl})$, which is different from the upper-middle reaches of the Shiyang River Basin, and ecological water conveyance aggravates the trend of transformation of the lake into brine.

(2) The time variation of ion concentration in Qingtu Lake is that it is high in the summer half year, large in change rate; low in the winter half year, small in change rate. The law of spatial variation is that of the unstable catchment is higher than that of the stable catchment.

(3) Silicate rock weathering and the evaporate rock crystallization are the important sources of water ions in Qingtu Lake, and the precipitation has little influence on the water characteristics of Qingtu Lake.

(4) The main positive ecological effects brought by ecological water conveyance in Qingtu Lake are the increase of vegetation coverage and phreatic rise. The negative effect is the shortage of water resources in the middle reaches, the aggravation of downstream lake water, and soil salinization.

Author Contributions: Formal analysis, Y.Z.; funding acquisition, G.Z.; methodology, H.M. and Y.Z.; data curation, H.G. and Y.Z.; software, J.Y. and Y.Z.; validation, H.P. and H.M.; project administration, Q.W.; investigation, L.Y. and Y.Z.; writing—original draft preparation, Y.Z.; writing-review and editing, G.Z. and H.M.

Funding: This research was financially supported by the National Natural Science Foundation of China (41867030, $41661005,41761047)$, the National Natural Science Foundation innovation research group science foundation of China (41421061), and the Autonomous Project of State Key Laboratory of Cryosphere Sciences (SKLCS-ZZ-2017).

Acknowledgments: We would like to thank the colleagues in the Northwest Normal University for their help in writing process. We would like to thank our colleagues in the State Key Laboratory of Cryospheric Science, Northwest Institute of Eco-Environmental Resources, Chinese Academy of Sciences for their help in the process of sample analysis. We are grateful to anonymous reviewers and editorial staff for their constructive and helpful suggestions.

Conflicts of Interest: The authors declare no conflicts of interest.

Data Availability Statement: The data that support the findings of this study are available on request from the corresponding author. The data are not publicly available due to privacy or ethical restrictions.

\section{References}

1. Jones, B.F.; Eugster, H.P.; Rettig, S.L. Hydrochemistry of the lake Magadi basin, Kenya. Geochim. Cosmochim. Acta 1977, 41, 53-72. [CrossRef]

2. Spencer, R.J.; Eugster, H.P.; Jones, B.F.; Rettig, S.L. Geochemistry of Great salt Lake, Utah I: Hydrochemistry since 1850. Geochim. Cosmochim. Acta 1985, 49, 727-737. [CrossRef]

3. Gibbs, R.J. Mechanisms controlling world water chemistry. Science 1970, 170, 1088-1090. [CrossRef] [PubMed]

4. Wetzel, R.G. Limnology: Lake and River Ecosystems; Gulf Professional Publishing: Oxford, UK, 2001.

5. Chen, Y.J.; Chen, Y.N.; Liu, J.Z.; Li, W.; Li, J.; Xu, C. Dynamical variations in groundwater chemistry influenced by intermittent water delivery at the lower reaches of the Tarim River. J. Geogr. Sci. 2005, 15, 13-19. [CrossRef]

6. Stottlemyer, R.; Toczydlowski, D. Stream chemistry and hydrologic pathways during snowmelt in a small watershed adjacent Lake Superior. Biogeochemistry 1991, 13, 177-197. [CrossRef]

7. Micklin, P. The Aral Sea Disaster. Annu. Rev. Earth Planet. Sci. 2007, 35, 47-72. [CrossRef] 
8. Chen, Y.N.; Zhang, X.L.; Zhu, X.M.; Li, W.H.; Zhang, Y.M.; Xu, H.L.; Zhang, H.F.; Chen, Y.P. Water transportation and eco-environmental effects in the lower reaches of Tarim River. Sci. China 2004, 34, 475-482.

9. Arthington, A.H.; Pusey, B.J. Flow restoration and protection in Australian rivers. River Res. Appl. 2010, 19, 377-395. [CrossRef]

10. Smakhtin, V.U.; Gamage, N.; Bharati, L. Hydrological and environmental issues of interbasin water transfers in India: A case of the Krishna River Basin//IWMI Conference Proceedings. Int. Water Manag. Inst. 2008, 1, 127-130.

11. Davies, B.R.; Thoms, M.; Meador, M. An assessment of the ecological impacts of inter-basin water transfers, and their threats to river basin integrity and conservation. Aquat. Conserv. Mar. Freshw. Ecosyst. 1992, 2, 325-349. [CrossRef]

12. Walker, K.F.; Sheldon, F.; Puckridge, J.T. A perspective on dryland river ecosystems. River Res. Appl. 2010, 11, 85-104. [CrossRef]

13. Zhuang, W. Eco-environmental impact of inter-basin water transfer projects: A review. Environ. Sci. Pollut. Res. 2016, 23, 12867-12879. [CrossRef]

14. Karthe, D. Environmental changes in Central and East Asian drylands and their effects on major river-lake systems. Quat. Int. 2018, 475, 91-100. [CrossRef]

15. Micklin, P. The future Aral Sea: Hope and despair. Environ. Earth Sci. 2016, 75, 844. [CrossRef]

16. Aishan, T.; Halik, Ü.; Cyffka, B.; Kuba, M.; Abliz, A.; Baidourela, A. Monitoring the hydrological and ecological response to water diversion in the lower reaches of the Tarim River, Northwest China. Quat. Int. 2013, 311, 155-162. [CrossRef]

17. Guo, N.; Liang, Y.; Wang, X.P. Remote sensing monitoring and analysis on effect of environmental recovery in lower reaches of Heihe River due to re-distributing runoff. J. Desert Res. 2004, 24, 740-744.

18. Zhang, M.M.; Wang, S.A.; Fu, B.J.; Gao, G.Y.; Shen, Q. Ecological effects and potential risks of the water diversion project in the Heihe River Basin. Sci. Total Environ. 2018, 619, 794-803. [CrossRef]

19. Zhu, G.F.; Zhang, Y.; He, Y.Q.; Zhou, J.J.; Pan, H.X.; Guo, H.W.; Ma, H.Y.; Ma, X.G.; Feng, L. Hydrochemical assessment of the largest desert reservoir in arid oasis area in Asia. Environ. Earth Sci. 2018, 77, 765. [CrossRef]

20. Yang, Y.C.; Li, J.J.; Chen, F.H.; Burgess, J.; Li, R.C.; Li, D.; Chang, G.Y.; Li, Y.C. The human mechanism research of Minqin Oasis change in the lower reaches of the Shiyang River. Geogr. Res. 2002, 21, 449-458. [CrossRef]

21. Zhao, J.; Yang, J.X.; Zhu, G.F. Effect of ecological water conveyance on vegetation coverage in surrounding area of the qingtu lake. Arid Zone Res. 2018, 35, 1251-1261.

22. Chunyu, X.Z.; Huang, F.; Xia, Z.Q.; Zhang, D.R.; Chen, X.; Xie, Y.Y. Assessing the ecological effects of water transport to a lake in arid regions: A case study of Qingtu Lake in Shiyang River basin, Northwest China. Int. J. Environ. Res. Public Health 2019, 16, 145. [CrossRef]

23. Dong, Z.L.; Xu, X.Y.; Jin, H.X.; Liu, S.J.; Zhang, J.H.; Tang, W.D.; Wang, X.H. The impact of eco-water transportation to the vegetation in tail lake of Shiyang River. J. Arid Land Resour. Environ. 2015, 7, 101-106.

24. Shi, W.L.; Liu, S.J.; Liu, S.Z.; Yuan, H.B.; Ma, J.P.; Liu, H.J.; An, F.B. Influence analysis of artificial water transfer on the regional ecological environment of Qingtu Lake in the lower reaches of the Shiyang River. Acta Ecol. Sin. 2017, 37, 5951-5960. [CrossRef]

25. Zhu, G.F.; Guo, H.W.; Qin, D.H.; Pan, H.X.; Zhang, Y.; Jia, W.X.; Ma, X.G. Contribution of recycled moisture to precipitation in the monsoon marginal zone: Estimate based on stable isotope data. J. Hydrol. 2019, 569, 423-435. [CrossRef]

26. Zhao, P.; Xu, X.Y.; Qu, J.Y.; Li, Y.; Jiang, S.X.; Zhang, Y.N. Characteristics of $d$ and $\delta \sim(18) o$ in precipitation in qingtu lake area, at lower reaches of shiyanghe river and its water vapor sources. J. Arid Land Resour. Environ. 2019, 33, 81-85.

27. Liu, R.R.; Lu, B.H.; Xu, D.; Zhang, J.; Zhai, M.E.; Chang, N.; Li, L.H. Changes of evaporation and its influencing factors in shiyang river basin. J. China Hydrol. 2013, 331, 82-93.

28. Zhao, X.Y.; Zhao, H.L.; Liu, C.F. The farmers' livelihood risk and their coping strategy in the downstream of Shiyang River: A case of Minqin Oasis. Geogr. Res. 2015, 34, 922-932.

29. Zhu, G.F.; Pu, T.; He, Y.Q.; Shi, P.J.; Zhang, T. Seasonal variations of major ions in fresh snow at Baishui Glacier No. 1, Yulong Mountain, China. Environ. Earth Sci. 2013, 69, 1-10. [CrossRef] 
30. Yang, L.; Zhu, G.F.; Shi, P.J.; Li, J.F.; Liu, Y.F.; Tong, H.L.; Hu, P.F.; Liang, F.; Pan, H.X.; Guo, H.W.; et al. Spatiotemporal characteristics of hydrochemistry in Asian arid inland basin-a case study of Shiyang River Basin. Environ. Sci. Pollut. Res. 2018, 25, 2293-2302. [CrossRef]

31. Shen, Z.L. Hydrogeochemistry Base; Geological Publishing House: Beijing, China, 1993.

32. Maidment, D.; Stedinger, J.; Vogel, R.; Foufoulageogious, E.; Pilgrim, D.; Cordery, I. Handbook of hydrology. Earth Sci. Rev. 1993, 24, 227-229.

33. Piper, A.M. A graphic procedure in the geochemical interpretation of water-analyses. Eos Trans. Am. Geophys. Union 1944, 25, 914-928. [CrossRef]

34. Zhu, G.F.; He, Y.Q.; Pu, T.; Zhang, N.N.; Wang, S.X.; Xin, H.J. Character and sources of conventional anion in different water bodies on the summer in Yulong Snow Mountain area. Environ. Sci. 2011, 32, 626-631.

35. Gaillardet, J.; Dupré, B.; Louvat, P.; Allegre, C.J. Global silicate weathering and $\mathrm{CO}_{2}$, consumption rates deduced from the chemistry of large rivers. Chem. Geol. 1999, 159, 3-30. [CrossRef]

36. Kenoyer, G.J.; Bowser, C.J. Groundwater chemical evolution in a sandy silicate aquifer in northern wisconsin: 1. patterns and rates of change. Water Resour. Res. 1992, 28, 579-589. [CrossRef]

37. Chen, L.J.; Feng, Q.; Wang, Y.; Yu, T.F.; Su, Y.H. Groundwater environment variation in the Minqin Oasis. J. Arid Land Resour. Environ. 2012, 26, 8-13.

38. Li, Y.H.; Feng, Q.; Chen, L.J.; Zhao, Y.; Yang, H.D. Hydrochemical Characteristics and Evolution Mechanism of Groundwater in the Minqin Oasis. Arid Zone Res. 2017, 34, 733-740.

39. Shi, Y.F.; Shen, Y.P.; Li, D.L.; Zhang, G.W.; Ding, Y.J.; Hu, R.J.; Kang, E.S. Discussion on the present climate change from warm-dry to warm-wet in Northwest China. Quat. Sci. 2003, 23, 152-164. [CrossRef]

40. Stocker, T.; Qin, D.; Plattner, G. IPCC, 2013: Climate Change 2013: The Physical Science Basis. Contribution of Working Group I to the Fifth Assessment Report of the Intergovernmental Panel on Climate Change//of the Intergovernmental Panel on Climate Change; IPCC: Geneva, Switzerland, 2013; pp. 710-719.

41. Richter, B.; Baumgartner, J.; Wigington, R.; Braun, D. How much water does a river need? Freshw. Biol. 1997, 37, 231-249. [CrossRef]

(C) 2019 by the authors. Licensee MDPI, Basel, Switzerland. This article is an open access article distributed under the terms and conditions of the Creative Commons Attribution (CC BY) license (http://creativecommons.org/licenses/by/4.0/). 